\title{
Migratory Activities in Caged Emberiza rustica Exposed to Different Artificial Lights and Temperatures
}

\author{
Tsukasa Nakamura* and Masahiko Kitahara**
}

\begin{abstract}
The migratory activities or Zugunruhe in caged Emberiza rustica have been studied. The experiment was conducted by exposing the above species to different artificial temperatures in three chambers which were maintained at $22^{\circ} \mathrm{C}, 15^{\circ} \mathrm{C}$ and $8^{\circ} \mathrm{C}$, respectively. The photoperiod was increased from 9 to 15 hours and then decreased from 15 to 9 hours during the period from March to December, 1978. The activities in the darkness, Zugunruhe of the bird group exposed to $22^{\circ} \mathrm{C}$ increased in July and August and terminated in September; and in the $15^{\circ} \mathrm{C}$ group, moderate Zugunruhe appeared only in July. In the $8^{\circ} \mathrm{C}$ group, however, slight Zugunruhe appeared only in July and then increased Zugunruhe appeared in September. Thus, all three different temperatures induced the onset of Zugunruhe in spring, however, it was at a low temperature such as $8^{\circ} \mathrm{C}$ that Zugunurhe was induced both in spring and in autumn.
\end{abstract}

\section{Introduction}

There have been many studies on environmental factors that control the induction of migration, and it has been confirmed from experimental data that the onset of migration is controled by the annual cycle of day length. Among them, some reports showed that the annual cycle of day length is an environmental factor which controls the onset of migration (Berthold 1973, 1974, Berthold et al. 1972, Farner 1950, 1955, 1958, 1964, Farner et al. 1953, 1954, King 1963a, 1963b, Wolfson 1952, 1970 and others). However, only a few studies have been done on the ambient temperature as an environmental factor to control the induction of migration. Lewis and Farner (1973) reported in a series of their studies that the induction of usual migration by the time of the onset of Zugunruhe and the timing of fattening is favoured by moderately high ambient temperature. Nakamura (1980a, 1980b) and Nakamura et al. $(1976,1982)$ have made a series of studies on the annual cycle of day length as an environmental factor which induces migration using Emberiza rustica and Emberiza schoeniclus and confirmed that the annual cycle of day length is the most crucial environmental factor. The authors made a research on how the onset of migration is influenced by the ambient temperature.

In this paper, we report a result from a series of studies on the annaul cycle of day length and the ambient temperature which induce migration.

\section{Materials and Methods}

Materials used in the present study was Kamchatkan Rustic Bunting, Emberiza

\footnotetext{
Received 31 May 1983

* Department of Biology, Yamanashi University, Kofu 400, Japan.

** Sundai Kofu High School, Kofu 400, Japan.
} 
rustica which were collected by mist nets near the River Fuji and the River Fuefuki near the Sangun Bridge which is located about $20 \mathrm{~km}$ south east of Kofu, Yamanashi Prefecture, Honshu. Birds were caged separately in small bamboo cages $(32 \mathrm{~cm} \times 18 \mathrm{~cm} \times$ $24 \mathrm{~cm}$ ), which were equipped with perch microswitches connected to a computer in order to record the locomotor activity (perch hopping). The experiment was conducted by exposing migratory E. rustica to different artificial temperatures in three chambers (NK type $78 \mathrm{~cm} \times 107 \mathrm{~cm} \times 52 \mathrm{~cm}$ ) which were maintained at $22^{\circ} \mathrm{C}, 15^{\circ} \mathrm{C}$ and $8^{\circ} \mathrm{C}$, respectively. Each chamber was lighted by two 15-Watt fluorescent lumps. The photoperiod was increased from 9 to 15 hours and then decreased from 15 to 9 hours during the period from March through December.

\section{Results}

1. Body weight

Monthly changes in the body weight of individual birds of three bird groups

i. Bird group exposed to a temperature of $8^{\circ} \mathrm{C}$

Among individual birds of the group exposed to a temperature of $8^{\circ} \mathrm{C}$, the body weight of a bird $r$ gradually increased from March through October. The body weight of bird b increased from March through June with the maximun of $24.7 \mathrm{~g}$, then decreased from July through October. The body weight of a bird g increased from March through July and the maximum weight during that period was $27.4 \mathrm{~g}$. The bird $\mathrm{g}$ decreased its body weight since then through the whole experimental period. A bird y increased its body weight from March through April. A bird o showed a noticeable increase in its body weight from March through June. The bird group exposed to a temperature of $8^{\circ} \mathrm{C}$, in general, increased their body weights from March through June, and most of the birds in this group showed rather remarkable increase in their body weights. From July through December, some of the birds in this group decreased their body weights while others showed no change in their body weights. Most of the birds in this group reached their weight maxima during the month of June or July.

ii. Bird group exposed to a temperature of $15^{\circ} \mathrm{C}$

Among the bird group exposed to a temperature of $15^{\circ} \mathrm{C}$, a bird $\mathrm{r}$ showed an increase in its body weight from March through June with the body weight maximum of $26.2 \mathrm{~g}$. The body weight of the bird $\mathrm{r}$ decreased from July through October. This bird showed a remarkable increase in its body weight during April and May and a noticeable decrease during July and August. While a bird b increased from March through May, a bird $\mathrm{g}$ increased from March through October and showed no change from October through December. In other words, the bird g showed no decrease in its body weight through the whole experimental period. A bird o increased from March through June with the maximum body weight of $28.1 \mathrm{~g}$, then the weight decreased from July through September. In general, the body weights of the bird group exposed to a temperature of $15^{\circ} \mathrm{C}$ increased from March through June and then decreased from July through October. Most of the birds in this group reached their body weight mixima during the month of June. 
iii. Bird group exposed to a temperature of $22^{\circ} \mathrm{C}$

Among individual birds of the group exposed to a temperature of $22^{\circ} \mathrm{C}$, a bird $\mathrm{r}$ increased from March through June with its weight maximum of $22.5 \mathrm{~g}$, then it decreased remarkably until September. A bird b, decreased its body weight in March and early in April, however, it increased remarkably from late April through June with the maximum of $22.5 \mathrm{~g}$. A bird $\mathrm{g}$, increased from March through June and the maximum weight was $27.7 \mathrm{~g}$. Then it decreased remarkably in July and in August, however, it increased again in September. A bird y, increased remarkably from March through June and the maximum weight of $24.7 \mathrm{~g}$. Then it decreased from July through October. A bird o increased its body weight from March through June and the maximum weight was $23.3 \mathrm{~g}$.

To sum up, individual birds in the group exposed to a temperature of $22^{\circ} \mathrm{C}$, in general, increased their body weights from March through June. Then the birds in this group decreased their body weights from July through October. Most of the birds in this group reached their body weight maxima in June.

iv. Distinctive patterns of body weight changes in some birds

Most of the birds in the three groups showed rather similar patterns of changes in their body weights through the whole experimental period. However, some birds showed distinctive patterns of changes in their body weights such as birds $r$ and $o$ in the group exposed to a temperature of $8^{\circ} \mathrm{C}$, the bird $\mathrm{g}$ in the group exposed to a temperature of $15^{\circ} \mathrm{C}$, and bird $\mathrm{b}$ and $\mathrm{o}$ in the group exposed to a temperature of $22^{\circ} \mathrm{C}$. Some of them increased their body weights through the whole experimental period while others showed rather distinctive curves of their body weight change.

\section{Monthly changes in the mean body weights of the three bird groups}

Fig. 1. showed monthly changes in the mean body weights of the three groups exposed to different temperatures, $8^{\circ} \mathrm{C}, 15^{\circ} \mathrm{C}$, and $22^{\circ} \mathrm{C}$. The mean body weight of the group exposed to a temperature of $22^{\circ} \mathrm{C}$ was about 3 grams heavier than that of the bird group exposed to a temperature of $15^{\circ} \mathrm{C}$ through the whole experimental period. However, patterns of monthly changes in the mean body weights of these two groups were similar to each other. The mean body weights of these two groups increased from March through June, and then decreased until September. In the two groups, they reached the mean body weight maxima in June and July. In the group exposed to a temperature of $8^{\circ} \mathrm{C}$, the mean body weight of the birds increased from March through July and the pattern of changes in the mean body weight during this period was similar to that of changes in the mean body weight of the other two groups exposed to temperatures of $22^{\circ} \mathrm{C}$ and $15^{\circ} \mathrm{C}$ during the same period of time. However, the mean body weight of the group exposed to a temperature of $8^{\circ} \mathrm{C}$ slightly decreased from July to October in comparison with the steady decrease in the mean body weights of the other two groups exposed to temperatures of $15^{\circ} \mathrm{C}$ and $22^{\circ} \mathrm{C}$. The bird group exposed to a temperature of $8^{\circ} \mathrm{C}$ reached the mean body weight maximum in July. The mean body weights of the group exposed to a temperature of $15^{\circ} \mathrm{C}$ from March through July were about 3 grams heavier than those of the groups exposed to temperatures of $8^{\circ} \mathrm{C}$ and $22^{\circ} \mathrm{C}$. From July through December, the mean body weight of the group exposed to 


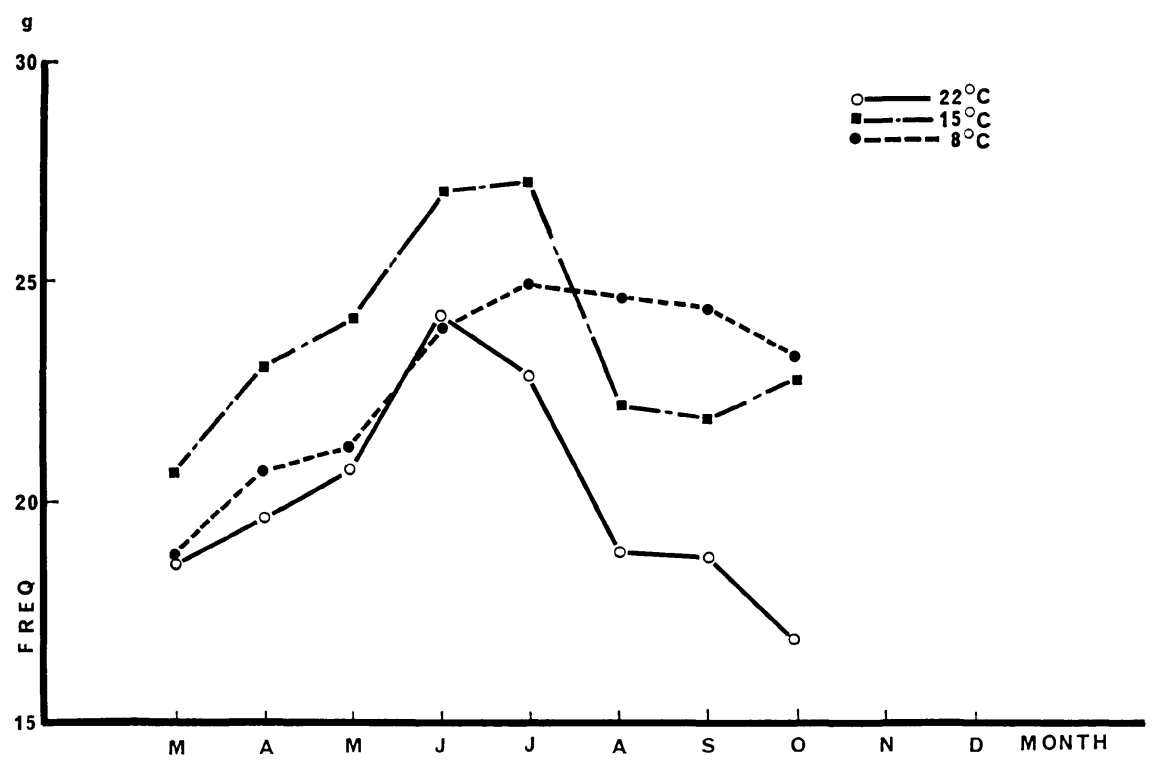

Fig. 1. Mean body weights of Emberiza rustica exposed to different temperatures of $8^{\circ} \mathrm{C}$, $15^{\circ} \mathrm{C}$ and $22^{\circ} \mathrm{C}$.

a temperature of $8^{\circ} \mathrm{C}$ was the heaviest among the three groups and that of the groups exposed to a temperature of $15^{\circ} \mathrm{C}$ was heavier than that of the group exposed to a temperature of $22^{\circ} \mathrm{C}$.

The mean body weights of the group exposed to temperatures of $8^{\circ} \mathrm{C}, 15^{\circ} \mathrm{C}$, and $22^{\circ} \mathrm{C}$ during the month of March were $18.7 \mathrm{~g}, 20.7 \mathrm{~g}$ and $18.7 \mathrm{~g}$, respectively. The mean body weight maxima of the bird groups exposed to temperatures of $8^{\circ} \mathrm{C}, 15^{\circ} \mathrm{C}$, and $22^{\circ} \mathrm{C}$ in July were $25.0 \mathrm{~g}, 27.2 \mathrm{~g}$ and $23.1 \mathrm{~g}$, respectively. The maximum mean body weight of all the birds during the whole experimental period was $29.4 \mathrm{~g}$, which was obtained from the bird y in the group exposed to a temperature of $15^{\circ} \mathrm{C}$ during the month of June. The minimum mean body weight of all the birds was $12.2 \mathrm{~g}$, which was obtained from the bird $\mathrm{r}$ of the group exposed to a temerature of $22^{\circ} \mathrm{C}$ in July and August.

\section{Locomotor activity of birds in the period of darkness}

Monthly changes in locomotor activity of individual birds in the period of darkness

i. Birds exposed to a temperature of $8^{\circ} \mathrm{C}$

The locomotor activity of the bird $r$ in the period of darkness increased both in July and September. The frequency of locomotor activity was 277 in July. However, in August locomotor activity of the bird decreased down to 15. The frequency of locomotor activity of the bird increased up to 511 in September, which was the highest throughout the experiment. No noticeable locomotor activity of the bird $r$ in the period of darkness could be observed in other months.

Locomoter activity of the bird $b$ in the period of darkness increased both in July and September. The frequency of locomotor activity of the bird in the period of darkness increased up to 236 in July, which was the highest of all the months, then 
decreased in August, and increased again up to 208 in September. No noticeable locomotor activity of the bird $b$ in the period of darkness was observed in other months. The frequency of the locomotor activity of the bird $\mathrm{g}$ in the period of darkness was 15 in July. However, no noticeable locomotor activity in the period of darkness was observed throughout the whole experimental period. Locomotor activity of the bird o in the period of darkness increased in July and September. The frequency of locomotor activity in the period of darkness was 38 in July, and increased up to 82 in September. Locomotor activity in the period of darkness was slightly observed in October, however, no noticeable locomotor activity in the period of darkness was observed in other months.

Thus, the birds in the group exposed to a temperature of $8^{\circ} \mathrm{C}$, in general, increased their locomotor activity in the period of darkness in July and in September and no noticeable locomotor activity in the period of darkness was observed in other months.

ii. Birds in the group exposed to a temperature of $15^{\circ} \mathrm{C}$

The bird $\mathrm{r}$ increased locomotor activity in the period of darkness remarkably in July and its frequency was 437. Slight locomotor activity in the period of darkness were observed in August, however, no noticeable locomotor activity in the period of darkness was observed in other months. Locomotor activity of the bird $b$ in the period of darkness increased in June and the frequency of the locomotor activity in the period of darkness was over 100. However, locomotor activity in the period of darkness decreased from July and no noticeable locomotor activity in the period of darkness was observed in other months. Locomotor activity in the bird $\mathrm{g}$ in the period of darkness increased in July and its freqeuncy was 111 , which was rather low compared with the high frequency of locomotor activity in the period of darkness of the bird r. However, in the bird g, the frequency of locomotor activity in the period of darkness in June and in August were higher than those of the bird $r$ in the same months. The frequency of locomotor activity of the bird $y$ in the period of darkness increased up to 396 in July. Slight locomotor activity in the period of darkness were observed in other months. Locomotor activity of the bird $o$ in the period of darkness were slightly observed both in July and in August, however, no noticeable locomotor activity was observed in other months. Thus in individual birds in the group exposed to a temperature of $15^{\circ} \mathrm{C}$, locomotor activity in the period of darkness increased in July and slight increase of locomotor activity in the period of darkness was observed in July and in August. However, no noticeable locomotor activity in the period of darkness was observed in other months.

iii. Birds exposed to a temperature of $22^{\circ} \mathrm{C}$.

Contrary to the general patterns of locomotor activity of the two bird groups exposed to temperatures of $8^{\circ} \mathrm{C}$ and $15^{\circ} \mathrm{C}$ in the period of darkness, the patterns of locomotor activity of individual birds exposed to a temperature of $22^{\circ} \mathrm{C}$ differed from one another. Each bird had its own pattern of locomotor activity in the period of darkness.

Locomotor activity of the bird $\mathrm{r}$ in the period of darkness increased in June and its frequency was 100 , and fairly active movements were observed during the months of April, May, and July. From March through June, locomotor activity in the period of darkness increased. Locomotor activity of the bird $b$ in the period of darkness 
increased in March and its frequency was 140. Then locomotor activity in the period of darkness decreased in April, however, they increased again in May and June, and the frequency of locomotor activity in the period of darkness increased up to 300 in July. Since then, locomotor activity in the period of darkness decreased until September. No noticeable locomotor activity in the period of darkness was observed in October through December. Locomotor activity of the bird $\mathrm{g}$ in the period of darkness increased in July and its frequncy was 214 , however, no noticeable locomotor activity in the period of darkness was observed in other months. This bird y showed extremely high frequencies of locomotor activity in the period of darkness among all the birds in the three groups. In July, its frequency increased up to 5,803, which was the highest of all the birds in the three groups. This bird showed rather high frequencies of locomotor activity in August and September and the frequency of locomotor activity in the period of darkness in August was 1,784, and that in September was 138. No remarkable locomotor activity was observed in other months. Locomotor activity of the bird $o$ in the period of darkness increased both in July and September.

To sum up, birds in the group exposed to a temperature of $22^{\circ} \mathrm{C}$, in general, increased their locomotor activity in the period of darkness from April through July. In individual birds, the frequency of locomotor activity in the period of darkness was the highest in July. Though there were some birds that showed frequent locomotor activity in the period of darkness in August and in September, locomotor activity in the period of darkness, as a whole, decreased in August and in September.

\section{Monthly changes in locomotor activity of the three bird groups in the period of darkness}

Patterns of locomotor acstivity in the period of darkness of the two groups exposed to temperatures of $15^{\circ} \mathrm{C}$ and $22^{\circ} \mathrm{C}$ were similar to each other throughout the experiment. In these two bird groups, the frequency of locomotor activity in the period of darkness increased in June and was the highest in July, then decreased in August. Contrary to the two groups exposed to temerature of $8^{\circ} \mathrm{C}$ increased their locomoror activity in the period of darkness in July and in September. The frequency of locomotor activity in the period of darkness was the highest in September in this group. No noticeable locomotor activity was observed in other months. In the three groups, locomotor activity in the period of darkness remarbably increased in July and it seems important that the difference of temperatures to which the bird groups were exposed had some effects upon the locomotor activity of the groups in the period of darkness. In July, the frequency of locomotor activity in the period of darkness of the group exposed to a temperature of $22^{\circ} \mathrm{C}$ was 1,587 , which was the highest among the three groups. The frequency of locomotor activity of the bird group exposed to a temperatures of $15^{\circ} \mathrm{C}$ was 240 , and that of the bird group exposed to a temperature of $8^{\circ} \mathrm{C}$ was 142 . Therefore, the higher a temperature to which a bird group was exposed was, the higher the frequency of locomotor activity in the period of darkness of the bird group in July increased. Only the bird group exposed to a temperature of $8^{\circ} \mathrm{C}$ increased their locomotor activity in the period of darkness in September, and the frequency of locomoror activity in the period of darkness of this group was 201. In the bird group exposed to a temperature of $22^{\circ} \mathrm{C}$, the frequency of locomotor activity in the period of darkness 


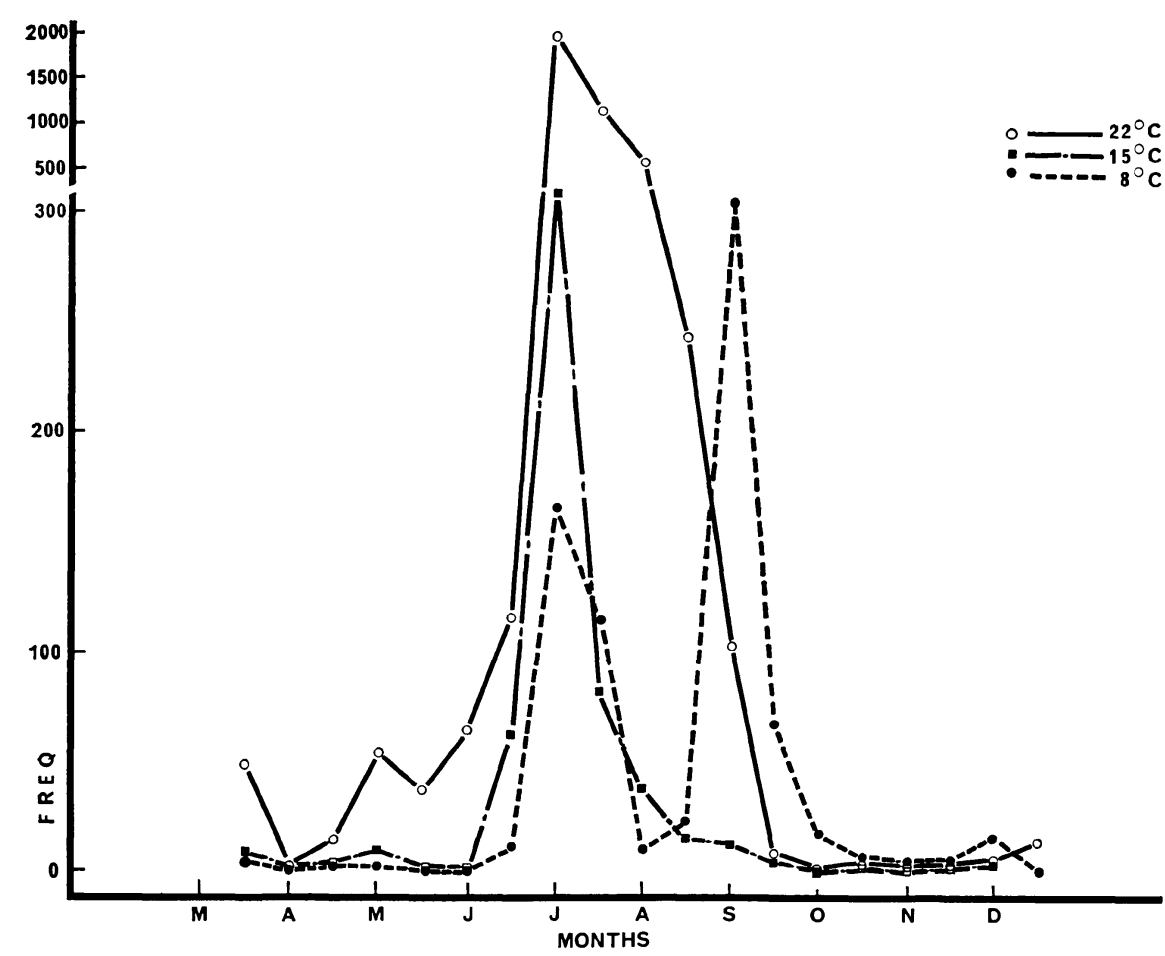

Fig. 2. Locomotor activity in the period of darkness in E. rustica exposed to temperatures of $8^{\circ} \mathrm{C}, 15^{\circ} \mathrm{C}$ and $22^{\circ} \mathrm{C}$.

was 57 in September. Thus in September the frequency of locomotor activity in the period of darkness of the group exposed to a temperature of $8^{\circ} \mathrm{C}$ was the highest among the three groups. The frequency of locomotor activity in the period of darkness of the group exposed to a temperature of $22^{\circ} \mathrm{C}$ was higher than that of the birds exposed to a temperature of $15^{\circ} \mathrm{C}$ in September.

\section{Locomotor activity of birds in the period of light}

Monthly changes in locomotor activity of individual birds in the period of light

i. Birds in the group exposed to a temperature of $8^{\circ} \mathrm{C}$

Locomotor activity of the bird $r$ in the period of light gradually decreased from March through Novemenber, however, slight increase in locomotor activity in the period of light was observed in June and in August. Locomotor activity of the bird $\mathrm{b}$ in the period of light increased in April and in August. The frequency of locomotor activity in the period of light in April was 4,046, and that in August was 4,404. Remarkable decrease in the locomotor activity in the period of light was observed in June and July. Locomotor activity of the bird $\mathrm{g}$ in the period of light increased in March, May, and September, and the frequencies of locomotor activity in March, May, and September were 3,472, 3,355, and 4,382, respectively. From July through August, the frequency of locomotor activity in the period of light was rather low. While locomotor activity of the bird $y$ in the period of light increased in March and 
in May, the frequency of locomotor activity in the period of light in March was 6,508, and that in May was 5,020. Decrease in locomotor activity in the period of light was observed in June. Locomotor activity of the bird o in the period of light increased in April, August, and November. The frequencies of locomotor activity in the period of light in April, August, and November were 3,572, 4,310, and 2,143, respectively. However, locomotor activity in the period of light dropped during the months of June and July and its frequency during that period decreased down to 2,000. In October, the frequency of locomoror activity in the period of light dropped again and decreased down to 1,558. Thus, in individual birds in the group exposed to a temperature of $8^{\circ} \mathrm{C}$, patterns of their locomotor activity in the period of light differed remarkably from one another. However, in most birds in this group, locomotor activity in the period of light increased in March, April, May, and August, and dropped during the months of June and July, and in October.

ii. Birds in the group exposed to a temperature of $15^{\circ} \mathrm{C}$

Locomotor activity of the bird $\mathrm{r}$ in the period of light of individual birds in the group exposed to a temperature of $15^{\circ} \mathrm{C}$ increased in the period of light in March, August, and November. The frequencies of locomotor activity in the period of light in March, August, and November were about 5,000 to 6,000. Locomotor activity in the period of light dropped from May through July, and in October. The frequency of locomotor activity in October decreased down to 1,302, which was the lowest through the whole experimental period.

In the bird b, locomotor activity in the period of light decreased from March through May, and then slightly increased in June. Locomotor activity in the period of light increased in March, July, August, and November, among them, the frequencies in July and in August were remarkably high, and were over 7,000. The locomotor activity in the period of light dropped in June and in October and the frequencies in June was 1,539, and that in October was 1,324. Locomotor activity of the bird $y$ in the period of light increased in May, and its frequency was 6,149. No noticeable locomotor activity was observed in other months. Locomotor activity of the bird $o$ in the period of light increased in May and in August. The frequency of locomotor activity in the period of light in May was 3,191, and that in August was 8,693, which was the highest of all the months. Locomotor activity dropped in June and the frequency of locomotor activity in the period of light in June was 849, and that in October was 7,731. Thus locomotor activity in the period of light remarkably increased from June to early August and decreased from late August to October. Birds in the group exposed to a temerature of $15^{\circ} \mathrm{C}$, in general, remarkably increased locomotor activity in the period of light from March through May, from July to August, and in November. However, locomotor activity in the period of light dropped in June, September, and October. In some birds, noticeable increase in locomotor activity in the period of light was observed in July and August.

iii. Birds in the group exposed to a temperature of $22^{\circ} \mathrm{C}$

The bird $\mathrm{r}$ slightly increased its locomotor activity in the period of light in May and in July, however, locomotor activity in the period of light dropped in April, June, and September. 


\section{Some remarks of changes in the body weight and the locomotor activity}

In the three bird groups exposed to temperatures of $8^{\circ} \mathrm{C}, 15^{\circ} \mathrm{C}$, and $22^{\circ} \mathrm{C}$, the body weights of all the birds, in general, increased from March through June and they reached their body weight maxima either in June or July. Contrary to the increase in the body weight, locomotor activity in the period of light decreased and those in the period of darkness incresed from March through June. Therefore, the birds in the three groups reached their body weight maxima around June, their locomotor activity in the period of light decreased down to the minima either in June or in July, and their locomotor activity in the period of darkness or Zugunruhe increased up to the maxima in the same month. It seems of interest that the temperatures to which the bird groups were exposed had some effects on the locomotor activity in the period of darkness. The higher the temperature to which the bird group was exposed was, the higher the frequency of locomotor activity in the period of darkness became. It is summarized as follows: The frequency of locomoror activity in the period of darkness of the bird group at $22^{\circ} \mathrm{C}>$ that of the bird group at $15^{\circ} \mathrm{C}>$ that of the bird group at $8^{\circ} \mathrm{C}$.

From June through August, locomotor activity in the period of darkness decreased and those in the period of light, conversely, increased up to their maxima. Body weights of all the birds in the three groups decreased in accordance with the decrease in locomotor activity in the period of darkness from June through August. The frequency of locomotor activity in the period of darkness in August was almost close to that in March. It is interesting enough to observe that in September locomotor activity in the period of darkness was observed only in the bird group exposed to a temperature of $8^{\circ} \mathrm{C}$. The birds in this group did not decrease their body weights in August and only slight decrease in this body weight was observed in September. Locomotor activity in the period of light in this group reached their maxima in August, and then decreased in September and in October, and increased again in November.

\section{Discussion}

\section{Body weight}

As shown in Fig. 1, the bird in the three groups exposed to temperatures of $8^{\circ} \mathrm{C}$, $15^{\circ} \mathrm{C}$, and $22^{\circ} \mathrm{C}$, remarkably increased their body weights from March to June or July, The birds in the three groups exposed to temperatures of $8^{\circ} \mathrm{C}$, and $22^{\circ} \mathrm{C}$ increased their body weights, on the average, body $6.24 \mathrm{~g}, 6.55 \mathrm{~g}$, and $5.48 \mathrm{~g}$, respectively. Locomotor activity in the period of darkness or Zugunruhe reached their maxima in July in the three groups. From the above results, it is inferred that the noticeable increase in their body weights from March to June or to July was due to the lipid accumulation prior to the migratory movement. Nakamura et al. (1978) reported that Zugunruhe increased with no sufficient lipid accumulation in the case of E. schoeniclus. However, in this experiment using E. rustica, Zugunruhe followed the increase in the body weight, namely, the lipid accumulation prior to the migratory movements which was observed in the three bird groups. However, in the group exposed to a temerature of $22^{\circ} \mathrm{C}$, the body weight reached its maximum in June, and then decreased in July. When the body 


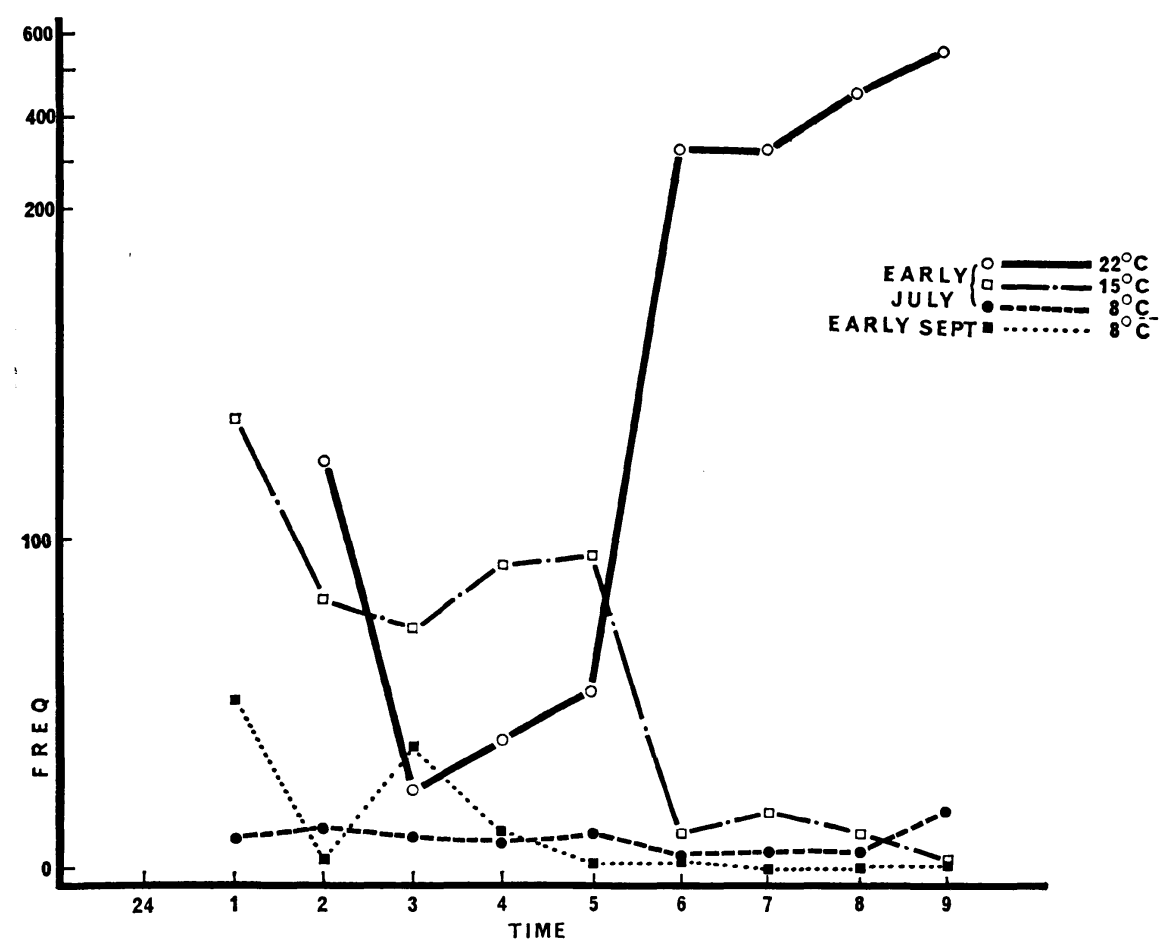

Fig. 3. Locomotor activity in the period of darkness in early July and early in E. rustica exposed to temperatures of $8^{\circ} \mathrm{C}, 15^{\circ} \mathrm{C}$ and $22^{\circ} \mathrm{C}$.

weight decreased in July, Zugunruhe reached its maximum, which seems of greast interest.

\section{Locomotor activity in cages}

In the two bird groups exposed to temperatures of $15^{\circ} \mathrm{C}$, and $8^{\circ} \mathrm{C}$, the frequencies of locomotor activity in the first half month of July were almost the same as that in the bird group of E. schoeniclus, one of the migratory birds of intermediate range, exposed to a temperature of $23^{\circ} \mathrm{C}$ in the same period of time (Nakamura et al. 1976). From the above results, it is inferred that the ambient temperature to which a bird is exposed has some effects on the quantity of its locomotor activity in the period of darkness.

In the vernal migration, E. rustica migrates, in general, from the wintering area like Japan to the northern breeding area, consequently, locomotor activity in the period of light increased at a rather high temperature in accordance with the mild and warm climate in the wintering area like Japan. In the bird group exposed to a temperature of $8^{\circ} \mathrm{C}$, locomotor activity in the period of darkness increased in July and in September. The increase in September was larger than that in July, therefore, it is inferred that the increase in locomotor activity in the period of darkness in September was due to the autumnal migration. In the autumnal migration, E. rustica migrates, in general, from the northern breeding area to the southern wintering area, consequently, locomotor ac- 


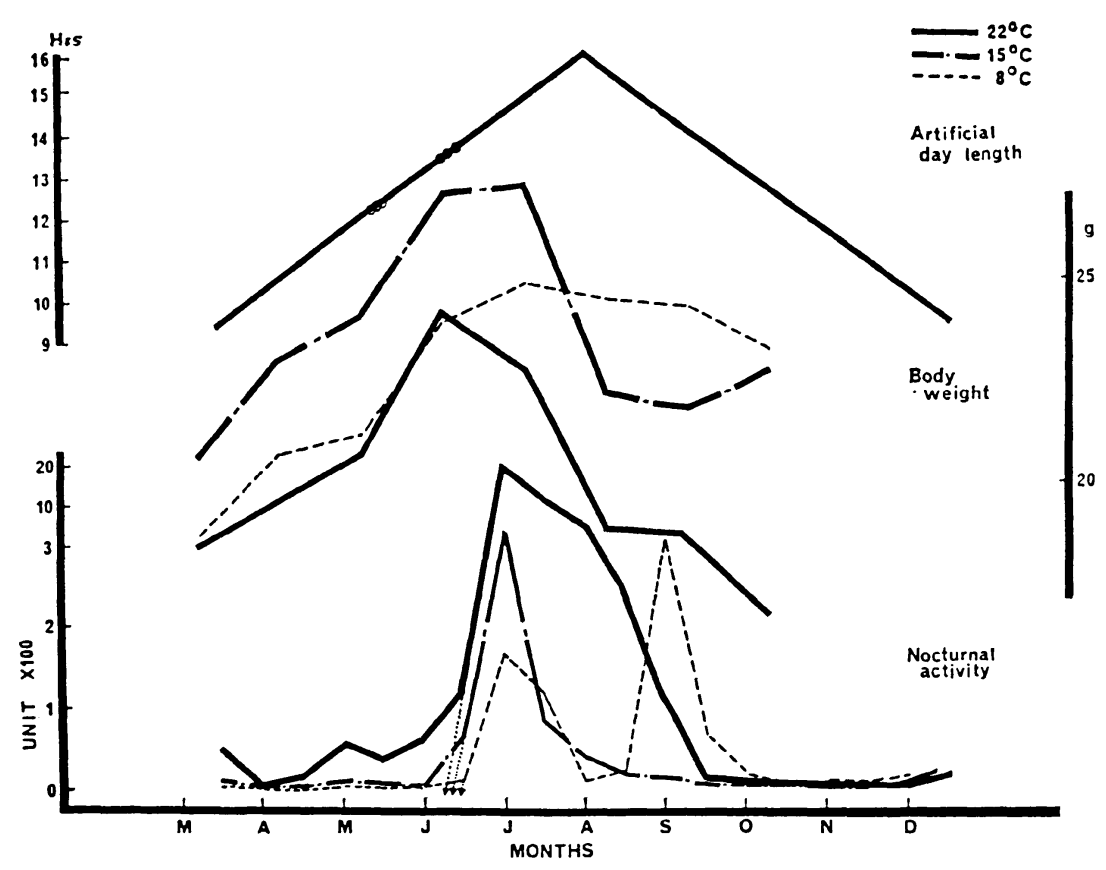

Fig. 4. Changes in body weights and locomotor activity in the period of darkness in E. rustica exposed to temperatures of $8^{\circ} \mathrm{C}, 15^{\circ} \mathrm{C}$ and $22^{\circ} \mathrm{C}$ in accordance with the increase and decrease in experimental photoperiod.

tivity in the period of darkness increase at a rather low temerature in accordance with the cold climate in the northern breeding area like Siberia.

Finally, let us examine how the onset of Zugunruhe was controlled by the annual cycle of day length. As stated previously, the onset of migration was controlled by the annual cycle of day length. In case of the vernal migration, the day length was about 13 hours at the onset of Zugunruhe.

\section{Locomotor activity in the period of light}

No remarkable similarity of patterns of locomotor activity in the period of light among the three bird groups was observed, however, there were some common tendencies in patterns of locomotor activity in the period of light among the three bird groups. In the three bird groups exposed to temperatures of $8^{\circ} \mathrm{C}, 15^{\circ} \mathrm{C}$, and $22^{\circ} \mathrm{C}$, locomotor activity in the period of light increased from March through May, from late July to August, and in November. However, locomotor activity in the period of light dropped in June and from September to October. It seems that the increase and the decrease in locomotor activity in the period of light were directly influenced by the migration and the breeding behavior. In June, September and October, locomotor activity of the three groups increased in the period of darkness and, conversely, decreased in the period of light. Therefore, the time when locomotor activity in the period of light decreased is correlated to the time of onset of migration. Furthermore, it is assumed that as loco- 
motor activity in the period of darkness increase, more energy is exhausted in the period of darkness, consequenctly, locomotor activity decrease in the period of light. In the three bird groups, locomotor activity in the period of light decreased in early July. However, locomotor activity in the period of light increased from late July to August, and this phenomenon seems to have something to do with the breeding behavior of the birds. In the northern breeding area such as Siberia, migratory birds breed from June to July. The increase in locomotor activity in the period of light from late July to August differed with the three groups; the increase in the group exposed to a temperature of $15^{\circ} \mathrm{C}$ was the largest among the three groups, and that in the groups exposed to a temperature of $8^{\circ} \mathrm{C}$ was larger than that in the group exposed to a temperature of $22^{\circ} \mathrm{C}$. Probably birds in the breeding period, tend to increase their locomotor activity in the period of light remarkably at a temperature of $15^{\circ} \mathrm{C}$. Increase in locomotor activity in the period of light was observed before vernal migration and after autumnal migration, that is, from June and in September, which has something to do with the wintering behavior of the birds. During the wintering period, behaviors are mainly feeding and repose. In this experiment, however, artificial day length was changed more rapidly than natural day length and environmental factors were rather different from those in the field, consequently, it cannot be explicitely confirmed that the increase in locomotor activity in the period of light before vernal migration and after autumnal migration is related to the wintering behavior of the birds. In November, their body weights of the bird groups exposed to temperatures of $15^{\circ} \mathrm{C}$, and $22^{\circ} \mathrm{C}$, increased up to their maxima either in June or in July and then decreased remarkably in August and in September. It is inferred that this noticeable decrease in their body weights in August and in September was due to the completion of migratory movements. After the completion of Zugunruhe the bird groups exposed to temperatures of $15^{\circ} \mathrm{C}$, and $22^{\circ} \mathrm{C}$ decreased their body weights by 5.36 and $7.13 \mathrm{~g}$, respectively. Their weights were close to those in March. The decrease in the body weight of the bird group exposed to a temperature of $22^{\circ} \mathrm{C}$ after the completion of Zugunruhe was greater than that of the bird group exposed to a temperature of $15^{\circ} \mathrm{C}$. As stated previously, the frequency of locomotor activity in the period of darkness of the bird group exposed to a temperature of $22^{\circ} \mathrm{C}$ was higher than that of the bird group exposed to a temperature of $15^{\circ} \mathrm{C}$ in July. The frequency of locomotor activity in the period of darkness of the group exposed to a temperature of $22^{\circ} \mathrm{C}$ was 1,587 , and their body weight decreased by $7.29 \mathrm{~g}$ in July. On the other hand, the frequency of locomotor activity in the period of darkness of the bird group exposed to a temperature of $15^{\circ} \mathrm{C}$ was 240 , and their body weight decreased by $5.136 \mathrm{~g}$ in July. From the above result, it is inferred that the increase in locomotor activity in the period of darkness was closely related to the decrease in the body weight. In the bird group exposed to a temperature of $8^{\circ} \mathrm{C}$, the body weight reached its maximum in July, and then slightly decreased in August and in September. The frequency of locomotor activity in the period of darkness of this bird group was 140 in July, which was the highest in this group, however, it was much lower than those of the bird groups exposed to temperatures of $15^{\circ} \mathrm{C}$ and $22^{\circ} \mathrm{C}$. Thus, in the bird group exposed to a temperature of $8^{\circ} \mathrm{C}$, the increase in locomotor activity in the period of darkness was closely related to the decrease in the body weight, as was observed in the 
bird groups exposed to temperatures of $15^{\circ} \mathrm{C}$ and $22^{\circ} \mathrm{C}$. In this bird group, the frequency of locomotor activity in the period of darkness reached its maximum in September and then decreased remarkably in October, November and December. To sum up, the decrease in the body weight had closely related to the increase in the locomotor activity in the period of darkness in all three bird groups.

\section{Locomotor activity in the period of darkness}

Monthly changes in locomotor activity in the period of darkness in the three bird groups exposed to temperatures of $8^{\circ} \mathrm{C}, 15^{\circ} \mathrm{C}$, and $22^{\circ} \mathrm{C}$ were previously shown in Figs. 2 and 4. To examine them in detail, semi-monthly changes in the above locomotor activity were shown in Fig. 3. The three bird groups increased their locomotor activity in the period of darkness in the first half month of July.

Taking the patterns of increase and its quantities of the three bird groups in this period into consideration, it is inferred that the increase in the locomotor activity in the period of darkness in the first half month of July was due to Zugunruhe prior to migratory movements. Though the increases in locomotor activity in the period of darkness in the first half month of July differed quantitatively with the three bird groups, all the three bird groups increased Zugunruhe prior to the migratory movements almost at the same time. From the above results, it is inferred that the induction of migratory movements was not directly influenced by the ambient temperature to which the bird was exposed as far as the ambient temperature ranged from $8^{\circ} \mathrm{C}$ to $22^{\circ} \mathrm{C}$. Therefore, the onset of migration seemed to be controlled mainly by the annual cycle of day length. Although the ambient temperature was not an decisive environmental factor to control the induction of migration, it had some effects on the onset of migration more or less since the increased in locomotor activity in the period of darkness in the first half month of July differed quantitatively with the three bird groups. As stated previously, in the first half month of July, that is, the time of the onset of vernal migration, the frequency of locomotor activity in the period of darkness in the bird group exposed to a temperature of $22^{\circ} \mathrm{C}$ was the largest among the three bird groups and the increase in the bird group exposed to a temerature of $15^{\circ} \mathrm{C}$ was larger than that in the bird group exposed to a temperature of $8^{\circ} \mathrm{C}$.

In this experiment using E. rustica, how migratory behavior in the birds was induced by environmental factors was studied. It was confirmed that the migratory movements were directly influenced not by the ambient temperature to which birds were exposed but by day length. In the three bird groups exposed to temperatures of $8^{\circ} \mathrm{C}$, $15^{\circ} \mathrm{C}$, and $22^{\circ} \mathrm{C}$, the onset of Zugunruhe was observed in the first half month of July when day length was about 13 hours. Thus, Zugunruhe began almost at the same time in the three bird groups regardless of the differences of temperatures. However, increase in locomotor activity in the period of darkness differed remarkably with the three groups, consequently, the ambinet temperature had some effects on locomotor activity in the period of darkness. The higher the ambient temperature to which birds were exposed was, the larger locomotor activity in the period of darkness increased. In the vernal migration period, the frequency of locomotor activity in the period of darkness in the bird group exposed to a temperature of $22^{\circ} \mathrm{C}$ was the largest among the three 
bird groups and that in the group exposed to a temperature of $15^{\circ} \mathrm{C}$ was higher than that in the group exposed to a temperature of $8^{\circ} \mathrm{C}$. In the autunmal migration period, Zugunruhe was observed only in the bird group exposed to a temperature of $8^{\circ} \mathrm{C}$, and the other two bird groups showed no Zugunruhe at all.

\section{Acknowledgements}

This research was supported in part by the scientific grant from the Ministry of Education, Japan. Authors are grateful to Miss Yukiko Amino for reading the English manuscript.

\section{References}

Berthold, P. 1973. Relationships between migratory restlessness and migration distance in Sylvia species. Ibis 115: 594-599.

Berthold, P. 1974. Migration: Control and metabolic physiology. (In Avian Biology), Farner and King ed., pp. 77-124.

Berthold, P., Gwinner, H. \& Westrich, P. 1972. Beziehungen zwischen Zugunruhe und Zugablauf bei Garten- und Mönchsgrasmücke (Sylvia borin und S. atricapilla). z. Tierphychol. 30: 26-35.

Farner, D. S. 1950. The annual stimulus for migration: Condor 52: 104-122.

Farner, D. S. 1955. The annual stimulus for migration: Experimental and physiological aspects. In "Recent Studies of Avian Biology" (A. Wolfson, ed.), 198-237. Univ. of Illinois Press Urbana.

Farner, D. S. 1958. Photoperiodism in animals with special reference to avian testicular cycles. Proc. 9th Annual Viol. Colloq. Oregon State College.

Farner, D. S. 1964 . The photoperiodic control of reproductive cycles of birds. Amer. Sci. 52: 37-56.

Farner, D. S. \& Mewaldt, L. R. 1953. The recording of diurnal activity patterns in caged birds. BirdBanding 24: 55-65.

Farner, D. S. Mewaltd, L. R. \& King, J. R. 1954. The diurnal activity patterns of caged migratory White-crowned Sparrow in late winter and spring. Comp. Physiol. Psychol. 47: 148-153.

Gwinner, E. 1975. Circadian and circannual rhythms in birds. In (Avian Biology, Farner and King ed.) vol. 5, pp. 221-274.

King, J. R. 1963a. Autumnal migratory fat deposition in the White-crowned Sparrow. Proc. Int. Ornithol. Congr., 13th, 1962 pp. 940-949.

King, J. R. 1963b. The relationship of fat deposition to Zugunruhe and migration. Condor 65: 200-223.

Lewis, R. A. \& Farner, D.S. 1973. Temperature modulation of photoperiodically induced vernal phenomena in White-crowned Sparrows (Zonotrichia leucophrys). Condor 75: 279-286.

Nakamura, T. 1980a. Activities of caged migratory Emberiza rustica exposed to different artificial lights and temperatures. Japan Sci. Soc. Press Tokyo, Spring Verlag. Berlin, p. 321.

Nakamura, T. 1980b. Activities of caged Emberiza schoeniclus exposed to different artificial lights and temperatures. ACTA 17th Congressus Internationalis Ornithologici, p. 1382.

Nakamura, T. Kurosawa, O. \& Ogihara, M. 1976. Activities of caged passerine birds exposed to artificial light and darkness. Miscellaneous Rep. Yamashina Inst. Ornith. 8: 89-94. (in Japanese with English summary).

Nakamura, T. Ito, M. \& Cho, K. 1982. Migratory activities of some Emberiza species exposed to different artificial lights and temperatures. 18th Congressus Internationalis Ornithologicus. Abstr. p. 315 .

Palmgren, P. 1949. On the diurnal rhythm of activity and rest in birds. Ibis 91: 561-576.

Wolfson, A. 1952. Regulation of spring migration in Juncos. Condor, 44: 237-263.

Wolfson, A. 1970. Light and darkness and circadian rhythms in the regulation of the annual reproductive cycle in birds. Colloq. Int. Cent. Nat. Rech. Sci. 172: 93-119. 


\section{人工照明及び温度下に飼育されたカシラダカのカゴ内における渡り活動}

鳥類の渡りの要因として重要である，日照と温度について，カシラダカを用い複合実験を試みた。 まず $22^{\circ} \mathrm{C}, 15^{\circ} \mathrm{C}, 8^{\circ} \mathrm{C}$ に一定にした 3 つの飼育室の日照時間を, 9 時間から 15 時間まで延長させ, 次 に 15 時間から 9 時間まで短縮させ,この間におけるカゴ内の鳥の活動を渡りの衝動を中心に測定した。 その結果, 日照時間, 13 時間から 14 時間にかけて, $22^{\circ} \mathrm{C}, 15^{\circ} \mathrm{C}, 8^{\circ} \mathrm{C}$ の グループとも, ほとんど同 時に渡りの衝動, つまり渡り行動が開始され, 温度差に関係なく, 日照時間のみによってその行動が起き た。

しかし渡りの活動量については，温度によりいろいろ差がみられた。

即ち, $22^{\circ} \mathrm{C}$ で飼育した鳥のグループは7 月から 8 月にかけて, 渡り行動が盛んになり, 9 月で終了した。 また $15^{\circ} \mathrm{C}$ のグループは 7 月に一度渡りの行動がみられた。また $8^{\circ} \mathrm{C}$ のグループは7月に小さな渡りの行 動が起り,さらに9月にも,より大きな渡り行動がみられた。

これらのことから，春の渡りは日照時間のみによって渡りがひき起こされることがわかった。しかし温 度は渡りの活動量を定める要因として働いていることがわかった。

中村 司: 山梨大学教育学部生物学教室. $干 400$ 甲府市武田 4 丁目 4-37. 北原正彦：駿台甲府高等学校. T400 甲府市塩部丁 2 丁目 8-1. 